\title{
Preparing critical teachers in University: The role of practicum in teachers' education Natassa Raikou
}

\section{Council for Innovative Research}

\author{
Peer Review Research Publishing System \\ Journal of Social Science Research
}

\author{
Vol.4, No.2 \\ editor@jssronline.com \\ www.cirworld.com, www.jssronline.com
}

\begin{abstract}
Summary
The text refers to the study of the preparation of future teachers at the University, focusing on the cultivation of critical reflection, as a necessary qualification for professional development. Special emphas is is given to practicum in education as part of their education, because in this area the student has the opportunity to be tested, to think and to reflect upon educational practices. This issue emerges from a survey conducted in the context of training preschool teachers in a Greek University. During the investigation, the need to strengthen the reflective skills of future teachers, as well as the potential benefits for their better preparation emerged.
\end{abstract}

\section{Introduction - The teachers' education}

Nowadays the debate on the need to revise traditional ways of learning is constantly growing (Jarvis, 1996; Rogers, 1999 \& 2003; Brookfield, 1983; Illeris, 2009). Moving from traditional to modern forms of education (distance learning, webbased courses, etc.), the need of adaptation to new environments is emerging (Karalis \& Koutsonikos, 2003). Common point on opinions expressed is that to achieve a change in the learning process, a prerequisite is the review and development of teachers' training (Raikou, 2012). The educator, as a social profession, is affected essentially by the socio-economic and cultural context within which takes part at a given historical moment. Once this framework is changing the teaching profession is also changing (Neave, 1998 \& Eurydice, 1996 as referred in Stamelos \& Vasilopoulos, 2004, p. 175).

To address contemporary is sues in educational, professional and personal level, it is necessary to overcome the sense of separation and fragmentation of the educational process (Karalis, Sotiropoulos \& Kampeza, 2007). The continuous training of teachers is taking place within multiple frames that extend beyond their initial education. According to the typology of Coombs (Coombs, 1968; Coombs \& Ahmed, 1974) training and leaming processes can be classified in one of the three types of education, which including the formal, non-formal and informal education. Formal education includes the hierarchically structured, chronologically graded education system, from primary school to university. The non-formal education refers to any organized educational activity outside the established educational system, addressed to specific public and based on specific training objectives. Finally, informal education contains all contexts within which individuals acquire knowledge, skils, attitudes and values from their daily experience and the effect of the environment, family, neighborhood, work, entertainment, the labour market, libraries and the media.

Taking into account this typology we realize that the teacher is exposed as a learner in multiple frames. In our country the initial training of pre-school and primary teachers, is done in university departments. In addition to formal education (university departments), the teacher is subject to both non-formal (seminars, trainings, etc.) as well as informal education. All three forms of education play a key role. Especially informal education, although its validity may be challenged since it doesn' t come from an organized educational institution, is of particular importance, because it affects constantly the professional identity of a teacher, shaping her/his perceptions and assumptions, affecting also their educational practices (Karalis, Sotiropoulos, \& Kampeza 2007, pp. 150-151). This effect can be achieved either through the social context (family, friends, acquaintances, media etc.), through the education area (school administration, colleagues etc.), or, finall y, through his earlier experience from the field of education. The latter is due to the fact that a teacher is exposed to practices throughout a student's life, from which draws patterns, attitudes and behaviors during the formation of his own practice (Greene, 1991).

However, many times the attitudes, norms and values which a teacher has embraced can be incorrect and thus leading to dysfunctional practices. Especially in the Greek context, which has a long tradition of a teacher centered education, this effect is critical for the reproduction of traditional practices delaying innovative methods. Therefore, the views of students about the learning process can influence and shape their attitude in the future, when they themselves teach. 


\section{Critical reflection on the teachers' education}

A frequent obstacle in education is the habit that feeds from the comfort of routine. Experienced teachers develop routines that simplify their professional lives. All those who have taught for several years have gain ways to do everything and organize the curriculum in ways that are relevant (Eisner, 2002, p. 3). There is a tendency for what Foucault calls nomalization, meaning a force imposing unifomity and allows people to define levels and contexts. These trends though and the prevalence of dominant social practices entrap us into molds (Greene, 2000, p. 135). To move from the mechanical chain of routines at times when, as reported by Camus, "the ' why ' is raised and everything starts in this torpor to be colored by surprise", is very important but very difficult (as above, p. 6). The educational objective of ' awakening ' concerns primarily the teacher but also the students. After all, the educational process includes all participants. As Freire says, "... in the educational process, the teacher-student and student-tutor are both knowledge Subjects, in front of knowledge objects "(1974, p. 20). That has more weight when it comes to the teachers' education, where the pupil is a prospective teacher. Therefore, according to Greene, the educational goal is to create situations in which "...trainees begin to ask, in all available voice tones Why" $(2000$, p. 6). The purpose of the teacher is to help students escape from the traditional habits of everyday perception, and to avoid the quick classification process in which we all resorting to continue our lives (Eisner, 2002, p. 68).

This means that the educator must be ready and open to new methods and modern practices. For this reason, proper preparation during their studies, with the cultivation of critical thinking and of stochastic process up to existing percepti ons, we would say that is a decisive factor for the formation of new teachers. For this to happen it is necessary, first to drive a process of critical reflection and examination of their consolidated perceptions, which are likely to hamper their professional development. Not only our previous experiences but also what we experience in the classroom promote critical reflection and dialogue, constituting the starting point of transformative learning (Taylor, 2009, p. 7). To learn from experience teachers should have time to think about the experience.

"To have an experience doesn't mean that you learn for this, but to have an experience, and then to think on this is learning ... Good teaching does not rely on a set of static, predefined rules and techniques, but changing circumstances require thoughtful teachers, who are concerned of teaching conditions and do not perceive them as a given, approaching any case with an open mind on what they know and the unknown "(Richert, 1991, p. 113).

There is an attempt within universities to meet these objectives, through the implementation of various programs, which offer ways of thinking, process and practice, adapted to each society (Raikou \& Karalis, 2007 \& 2010). Bas ed, however in the literature (Papaioannou, 2011), the programs, the teaching methods applied and the preparation of teachers, present deficiencies and gaps, both in terms of precise definition of the pedagogical objectives they pursue, and the accuracy and clarity of the general objectives of the knowledge and experience they provide. As Mackenzie says (1991, p. 95, as referred in Papaioannou, 2011), within universities "a mental authoritarian teaching method may not help students to escape from a mental servility".

To enable education to escape from a situation that Massey calls the cognitive malnutrition (1981, as referred in Papaioannou, 2011), it is necessary at all levels, particularly in higher education, to emphasize through courses, lectures and seminars, but mainly through practicum in education, in order to help students develop their logical abilities and trends, to be able to recognize the correct arguments that withstand criticism and most importantly to develop their own techniques for the development of critical thinking beyond what they have been taught. Teaching methods that develop and cultivate critical thinking in an educationally adequate way, becomes necessary in universities, so whatever knowledge and experience acquired can be integrated and be transmitted through everyday practice in schools (p. 103). Therefore, as a crucial emerging issue in the training of teachers is the cultivation conditions that promote thoughtful teachers, who have the ability to respond to changing circumstances. For educators, be reflectively involved and learn from their work requires time, opportunities and support. According to Richert, one way is to teach them how to operate reflectively, both during their professional career and before, during their training (p. 114). As described by Dewey (1933), thoughtful teacher faces the teaching as a mental order and not as a routine. Intellectual engagement provides the basis for empirical learning, in which a thoughtful teacher adapts what he knows in what he is experiencing in the changing world. In this way he creates new concepts and, thus, goes into revised actions.

\section{The role of practicum in education}

Considering all the above, we realize that, in the context of training and preparation of future teachers, practicum in education constitutes a very important part of their curriculum, as it offers them the possibility to link theory with practice and to come for the first time in contact with their professional environment and professional community (Karalis, Sotiropoulos \& Kampeza, 2007).

The practicum in education, as an essential learning experience, offers the opportunity to test the teaching skills and options, even wrong ones, to work supportively and help teaching capacity building. In addition, it can be a guide for prospective teachers, providing those tools that will make them aware of what they are looking for, reflect on their practice and also make them able to think a variety of approaches in their work. It can sharpen also their critical ability and perception in order to be able to "read" the data in their environment. This is enhanced even more through cooperation and debating of opinions between future teachers.

All this lay the foundation for a lasting relation of teaching with reflection, which constitutes a basic professional skill for a future educator. In this way she/he will be able to use strategies that facilitate reflection (at all levels, with emphasis on a critical self-reflection) to organize thought and action, that is to adapt appropriately the means and objectives of educational practice, to raise questions, to identify problematic situations and action and to find ways to overcome them. 


\section{An application example}

In the context of the curriculum in preschool teacher training department at the university of Patras, a series of workshops have been implemented, with the application of "Transformative Learning through Aesthetic Experience" method (Kokkos, 2011). Then the impact of these workshops was studied in relation to the practical exercise of female students, to detemine possible influences and variations. The aim of this action was to investigate the possibility for development of critical reflection among learners (Raikou, 2013).

The basic premise of the research was the longitudinal study of a group of students from the beginning of the second year until the completion of their studies. During this period students participated in a series of workshops designed and implemented based on the method of TLAE. The method used here is a six-stage path (Kokkos, 2011, pp. 97-100). It is a modern method which relies on the use of art, in order to strengthen and promote the development of critical reflection.

The research process was implemented in four steps and lasted respectively four years (2008-2011), meaning each academic year was a step in the investigation. The first year for the design and pilot phase of implementation of the method, while the remaining three years include the main application of research to a group of 15 students from the second through the fourth year of their studies. The topics discussed were issues of the leaming process, the role of teachers, teacher-leamer relationship, as well as planning and evaluation modules.

The qualitative analysis showed variations in reflection of trainees, which are associated with the implementation of the method observed. Particularly in the study of the degree of duration and scale of these changes, it was found that, in conjunction with the practicum in education, it is possible these changes to become pemanent and of wide character, providing the foundation for a continuous reflective process that will accompany teachers throughout their professional career.

The changes identified are important kinds of learning. Specifically, students:

a. Realize the educational role and their place in it, shaping, however, their personal perceptions, which are consolidating through the practicum in education. Characteristic are the views of some students about this topic:

"I was certainly influenced by our workshops, because we discussed a lot of things and I think it was good for me because I don't know if I have the opportunity to discuss these topics again in future. Now I think I have some bases and I have learned some things that I see also in kindergarten [in practice]" (VI').

"Our meetings (emphasis) certainly helped me! They were very constructive what we have seen ... I remember specially the film "The Wave", where at first it was a very peaceful professor. I always thought that it is a very fine line and you can very easily break it, so when I was in kindergarten for the first time with the kids, I remember that I was too well, no problem. This year l entered in another kindergarten, it's a different level and is a kid who causes trouble then, so at some point I caught being nervous but I figured that I shouldn't because it's just a kid and all images of the film came to me and I said: Okay, just calm down! " (VII).

"Our meetings have helped me a lot in this. Especially with what we did with the roles, helped me realize a lot of things. The seminars helped us from the very first meeting with the questions you posed us. What is a teacher? Based on this query you start and think what the teacher is? " (XI).

b. Acquire skills that help them to better prepare for the future on a professional level while taking into account the global coverage of the needs of leamers at both cognitive and emotional level. In addition, they do not separate theory from practice, but consider the theoretical approaches, the practical usefulness of the topic and understanding through experiential applications. As they reported:

"(In workshops) we saw more specific things that we had not taught elsewhere and we focused on them and it helped me to see myself as an educator ... I haven't changed my views but I have been influenced positively and I feel better man and teacher. I changed a lot in the way of thinking. More global thinking, and other modes of learning, teacher-leamer relationship, be more dialectic and open, more methodical and generally I saw several things that I can do as a future educator "(I).

"I had a different perception of how it is done, what is an educator, how relationships should be. Now I understand the frame, what there is. I haven't changed how I feel but I have different perception on the way. At first I didn't realize that I would become an educator, how and what this role is about. It was as a continuation of the school ... Seminars influenced me to grow up and think as a teacher what I don't do well, how others think, the participants in the educational process generally» (II).

\section{Synopsis}

The training of new teachers is a challenge. Both the literature and the contemporary socio-economic context in which we live lead to the need of the promotion of the cultivation of critical thinking as an essential aim of education. A fruitful place to start such a change is the education of future teachers in the University. Programs aimed at promoting students' reflective skills can enhance and affect catalytically the preparation of new teachers. Combined with practicum in education, which is an area for test, configuration and consolidation of critical reflection processes, the prospective teachers are introduced into the professional field well-equipped to contribute and improve the education provided today.

\section{References}

[1] Brookfield, S. D. (1983). Adult Learners, Adult Education and the Community. Buckingham: Open University Press.

[2] Coombs, P.H. \& Ahmed, M. (1974). Attacking Rural Poverty: How Non-Formal Education Can Help. Baltimore: John Hopkins University Press.

[3] Coombs, P.H. (1968). The World Educational Crisis: A Systems Analysis. New York: Oxford University Press.

[4] Dewey, J. (1933). How we think: A restatement of the relation of reflective thinking to the educative process. Chicago: Henry Regnery. 
[5] Eisner, E.W. (2002). The Arts and the Creation of Mind. New Heaven and London: Yale University Press. Freire, Paulo. Pedagogy of the oppressed. [New York]: Herder and Herder, 1970.

[6] Greene, M. (1991). Teaching: The Question of Personal Reality, In Lieberman, A. \& Miller, L., Staff Development for Education in the '90s: New Demands, New Realities, New Perspectives. Teachers College, Columbia University.

[7] Greene, M. (2000). Releasing the Imagination. San Francisco: Jossey-Bass.

Illeris, K. (2009). Contemporary Theories of Leaming, London: Routledge.

[8] Jarvis, P. (1996). Continuing Education in a Late-modern or Global Society: towards a theoretical framework for comparative analys is. Comparative Education, $32(2): 233-244$.

[9] Karalis, T. \& Koutsonikos, G. (2003). Issues and Challenges in Organising and Evaluating Web-based Courses for Adults, Themes in Education, 4:2, 177-188.

[10] Karalis, T., Sotiropoulos, L., \& Kampeza, M. (2007). La contribution de l'éducation tout au long de la vie et de l'anthropologie dans la préparation professionnelle des enseignants: réflexions théoriques. Skholê, Vol. hors série (1): 149-155.

[11] Kokkos, A. (2011). Transformative Learning through Aesthetic Experience: Towards a Comprehensive Method. Journal of Transformative Education, 8(3): 155-177.

[12] Mackenzie, J. (1991). On Teaching Critical Thinking. Educational Philosophy and Theory, 23 (1): 63.

[13] Massey, G. (1981). The Fallacy behind fallacies. Midwest Studies in Philosophy, 6: 489-500.

[14] Papaioannou, K. (2011). Critical thinking in education. New Education, 139: 90-105. [In Greek].

[15] Raikou, N. (2012). Can University Be a Transformative Environment? Fostering Critical Reflection through Art in Higher Education. Journal of Literature and Art Studies, 2 (3): 416-421.

[16] Raikou, A. (2013) Adult Education and Higher Education: Exploring the potential for developing critical thinking through aes thetic experience to teacher students. PhD Thesis. University of Patras [In Greek].

[17] Raikou, N. \& Karalis, T. (2007). Student Mobility from a Greek Perspective: Benefits and Difficulties as Expressed by the Participating Students. Higher Education in Europe, 32 (4): 347-357.

[18] Raikou, N. \& Karalis, T. (2010). Non-formal and informal education processes of European Lifelong Learning Programmes for Higher Education: The case of the Erasmus Programme in a Greek Peripheral University. International Journal of Interdisciplinary Social Sciences, 5.

[19] Richert, A. E. (1991). Using Teacher Cases for Reflection and Enhanced Understanding. In A. Lieberman \& L. Miller (Eds.), Staff Development for Education in the '90s. New York: Teachers College Press, 113-132.

[20] Rogers, A. (1996). Teaching Adults. Buckingham: Open University Press.

[21] Rogers, A. (2003). What is the difference? A new critique of adult learning and teaching. Leicester: NIACE.

[22] Stamelos, G. \& Vasilopoulos, A. (2004). European Educational Policy. Athens: Metechmio Press [In Greek].

[23] Taylor, E. (2009) Fostering Transformative Leaming. In J. Mezirow, E. Taylor \& Ass. Transformative Learning in Practice. San Francisco: Jossey-Bass. 